\title{
IEvaluation of the Effectiveness of Bokashis, Compost and Biopesticide Solution on the Productivity of Amaranth (Amaranthus hybridus) in Southern Benin
}

\author{
Ayidego Crépin Ebed HOUENOU ${ }^{1 *}$, Tatiana Windékpè KOURA ${ }^{1,2}$, Gustave Dieudonné \\ DAGBENONBAKIN² and GUY MERGEAl ${ }^{3}$ \\ ${ }^{1}$ Faculty of Agronomic Sciences (FSA), Applied Ecology Laboratory, University of Abomey-Calavi (UAC), Benin \\ ${ }^{2}$ National Institute of Agricultural Research of Benin, Benin \\ ${ }^{3}$ Tropical Agroecology Laboratory, University of Liège-Gembloux Agro-Bio Tech, Gembloux, Belgium
}

\begin{abstract}
Description of the subject: The problems linked to the decline in soil fertility, the losses caused by pests and diseases, the high cost of chemicals and the dangers linked to their misuse, require alternative strategies for sustainable production.

Objectives: To assess the effect of two bokashis (Bs and Bf), compost (Co) and biopesticide solution (EM5) promoted by the Songhaï agroecological center of Benin on the productivity of a leaf vegetable (amaranth) in southern Benin.

Methods: The field experiment was a split plot with 12 treatments. The main factor was the type of fertilizer used (Bs, $\mathrm{Bf}$ and $\mathrm{Co}$ ) at a dose of $20 \mathrm{t} / \mathrm{ha}$ and the couple "amendment application - frequency of application of the biopesticide" as a secondary factor ( $\mathrm{TO}=$ no amendment-no biopesticide, $\mathrm{T} 1=$ amendment only, $\mathrm{T} 2=$ amendment +1 biopesticide treatment/week and T3 = amendment +2 biopesticide treatments/week).

Results: The two bokashis significantly improved $(p<0.01)$ the production of amaranth compared to the control, whereas the application of the compost marketed by Songhaï did not result in a significant improvement in yields. The best results in terms of amaranth biomass production were obtained from treatments combining the supply of bokashi with one or two biopesticide sprays per week. The application of biopesticide significantly reduced the mortality rate $(\mathrm{P}<$ 0.05). The control treatments (CoTO, BsT0 and BfTO), bokashi Bf alone (BfT1) and with one biopesticide treatment per week (BfT2), and bokashi Bs alone (BfT1) generate a positive Gross Added Value (GAV).

Conclusion: Bokashis apply to $20 \mathrm{t} / \mathrm{h}$ a are likely to contribute to improving soil fertility and the productivity of vegetables including amaranth. Further investigations combining different application rate of bokashis are necessary to assess the effectiveness of bokashis on the productivity of vegetable crop. Songhai needs to improve its compost production process to increase its organic matter content and its fertilizing value.
\end{abstract}

Keywords

Bokashis, Compost, EM5, Amaranth, South-Benin

\section{Introduction}

Agriculture is one of the main sectors contributing to the economic development of developing countries. In Benin, it employs more than $42.36 \%$ of the active population (BIRDIDA, 2017); contributes $75 \%$ of export earnings, and provides around $70 \%$ of jobs [1]. In West Africa, market gardening constitutes one of the main components of urban and peri-urban agriculture which have developed strongly in recent decades following population growth and increased food needs [2-4]. In Benin, market gardening employs around $4 \%$ of the working population, or 60,000 jobs [4]. Real data indicate that the margin generated by vegetable production can reach 16.395
*Corresponding author: Ayidego Crépin Ebed HOUENOU, Faculty of Agronomic Sciences (FSA), Applied Ecology Laboratory, University of Abomey-Calavi (UAC), Benin, Tel: +229-94-93-83-87

Accepted: June 02, 2021

Published online: June 04, 2021

Citation: HOUENOU ACE, KOURA TW, Dieudonné G, et al. (2021) Evaluation of the Effectiveness of Bokashis, Compost and Biopesticide Solution on the Productivity of Amaranth (Amaranthus hybridus) in Southern Benin. J Hortic Sci Res 4(1):161-170 
Citation: HOUENOU ACE, KOURA TW, Dieudonné G, et al. (2021) Evaluation of the Effectiveness of Bokashis, Compost and Biopesticide Solution on the Productivity of Amaranth (Amaranthus hybridus) in Southern Benin. J Hortic Sci Res 4(1):161-170

million CFA francs/ha/year, or 4.31 billion on an area of 263 hectares exploited in 2000 [5,6]. However, market garden production in urban and peri-urban areas is limited by several factors such as the reduction of cultivated areas due to land tenure problems, the depletion of nutrient soils following their over exploitation and the vulnerability of crops to pests $[7,8]$. Thus, to remedy these problems, producers often use chemical fertilizers for soil fertilization and intensification of production, and synthetic pesticides to alleviate damage caused by pests [9].

Several studies have revealed that the use of chemicals (chemical fertilizers and pesticides) on crops in vegetable production compromises soil health; the quality of the environment and human health $[10,11]$. Indeed, the resistance of pests $[12,13]$, the elimination of natural enemies [14], the presence of pesticide residues in vegetables [15-17] and environmental pollution are all nuisances linked to the irrational use of synthetic products on market garden areas.

Among the guidelines taken to achieve sustainable production, many have shown their limits. Integrated production, using synthetic products as a last resort does not limit their uses, is also beginning to reach its limits: A lot of mechanization, little consideration of biodiversity and even copper and sulfur, products authorized for this production method, will soon be regulated because of their harmful effects on soils [18].

Agroecology is one of the solutions to the problems facing the world facing a number of crucial challenges: Feeding a growing, increasingly urban population, fighting against poverty and inequalities and ensure sustainable management of natural resources and the environment. Authors who revolutionized this concept, such as Altieri, Guzmán, originally defined agroecology in the strict sense of the term, as an attempt to integrate the principles of ecology into the redefinition of agronomy $[19,20]$. Nowadays, grace to social movements, agroecology is seen as a set of principles which in their own way contribute to finding alternatives to the dominant and failing agro-industrial system. Such principles take into account, among other things, the involvement and recycling of biomass [21], which has developed grace to new technologies for the recovery of organic matter, the invention and promotion of Efficient Microorganisms (EM) [22]. These various innovations developed make it possible to provide producers with a set of technologies that can be adapted to their environments.

In the context of central Benin, several practices are promoted. Among these, agroecological production, though the valorization of different forms of organic matter (compost, bokashi (fermented organic matter), manure, etc.), natural biopesticides and the use of effective microorganisms (EM) have been reported by the Songhai agroecological production center, as an alternative likely to improve the productivity of vegetables, significantly reduce the pressure of pests while contributing to the health of ecosystems.

Thus, the objective of this study is to assess the effectiveness of agroecological practices promoted by the Songhai center for the management of soil fertility and the control of pests in vegetable production, by the application of bokashis, compost and biopesticide solution based on "Effective Microorgranisms" (EM) on amaranth production in southern Benin.

\section{Materials and Methods}

\section{Study environment}

The study was conducted from 25 March to 22 June 2019, on the farm of the NGO-IAPEDEL (Agro-Pastoral and Economic Initiatives for Local Development), located between 6-32'36." $\mathrm{N}$ and 2-34'45.'E in the commune of Akpro-Missérété in south Benin. The experimental site was a market garden test plot that housed the cultivation of watermelon (Citrullus lanatus) in production without inputs. The soil of our experimental site has a sandy texture dominated by coarse sand (73.7\%). According to the characterization of soil fertility levels according to Quemada and Cabrera [23] cited by Igué, et al. 2013 [24], this soil is found in Class IV with a very low level of fertility. Limitations are noted at $\mathrm{N}(<0.047 \%), \mathrm{P}(0.8$ $\mathrm{mg} / 100 \mathrm{~g}), \mathrm{K}(<2.5 \mathrm{mg} / 100 \mathrm{~g})$ and CEC (1.5 meq/100 g).

\section{Fertilizers}

Three (3) fertilizers were used during experiments. The first bokashi made from bran and rice husk with Moringa leaves as ferment (Bs), produced with $50 \mathrm{~kg}$ of rice husk, $5 \mathrm{~kg}$ of rice bran, $16.5 \mathrm{I}$ of water, $0.495 \mathrm{I}$ of EM and honey and $5 \mathrm{~kg}$ of Moringa leaves. The second bokashi made from bran and rice husk with poultry litter as a starter (Bf), formulated with $40 \mathrm{~kg}$ of poultry manure, $20 \mathrm{~kg}$ each of bran and rice husk, 7.5 I of water, $0.075 \mathrm{dm}^{3}$ each one of honey and EM; and the third fertilizer, the compost based on decomposable kitchen waste from the Songhaï center ( $\mathrm{Co}$ ) and sewage sludge from fish ponds.

The preparation of the bokashis was made using the anaerobic fermentation method. The raw materials used and the quantities taken varied according to the type of bokashi. The formulation of our bokashis was carried out in three (3) steps: The first step consisted of sampling and homogeneous mixing in a basin of the liquid materials (honey, water and EMAS (Activated Solution of Effective Microorganisms)) using a graduated cylinder.

The second step consisted of sampling by weighing, followed by a homogeneous mixture of the solid raw materials (rice bran, rice husk, Moringa leaves or poultry litter).

The third step consisted in mixing the liquid and solid products previously obtained. Note that normal humidity was verified by the fist test. The various raw materials, namely EMAS, honey were purchased from the Songhaï center; the bran and rice husks come from the regional parboiling site of rice producers in Ouémé and Plateau, while Moringa leaves and poultry litter are obtained from the NGO-IAPEDEL site.

Several compost is produce in the Songhaï center. The compost used in this experience it obtained after recovery of decomposable waste from the kitchen section, combined with the sewage sludge from fish ponds and EMAS solution (Solution of Effective Microorganisms activated).

The different elements are added in successive layers, 
Citation: HOUENOU ACE, KOURA TW, Dieudonné G, et al. (2021) Evaluation of the Effectiveness of Bokashis, Compost and Biopesticide Solution on the Productivity of Amaranth (Amaranthus hybridus) in Southern Benin. J Hortic Sci Res 4(1):161-170

Table 1: Physico-chemical characteristics of the different fertilizers on the fresh basis.

\begin{tabular}{|l|l|l|l|l|l|l|l|l|}
\hline $\begin{array}{l}\text { Types of } \\
\text { fertilisers }\end{array}$ & $\begin{array}{l}\text { Dry matter } \\
\text { (DM) }\end{array}$ & Organic Matter (OM) & $\mathbf{p H}$ & $\mathbf{C / N}$ & $\mathbf{N}-\mathbf{N H}_{\mathbf{4}}^{+}$ & $\mathbf{N}$ & $\mathbf{P}_{\mathbf{2}} \mathbf{O}_{\mathbf{5}}$ & $\mathbf{K}_{\mathbf{2}} \mathbf{O}$ \\
\hline & & $\mathbf{6}$ & & & & \multicolumn{3}{|c|}{$\mathbf{k g / t}$} \\
\hline Bokashi Bf & 56.7 & 78.1 & 5 & 21.1 & 1.27 & 12.18 & 9.66 & 6.89 \\
\hline Bokashi Bs & 57.8 & 86.72 & 4.6 & 19 & 1.76 & 15.34 & 27.97 & 9.68 \\
\hline Compost & 76.2 & 10.11 & 7.6 & 10.5 & $<0.001$ & 4.28 & 6.97 & 3.44 \\
\hline
\end{tabular}

starting the previously with sewage sludge from fish ponds, followed by the kitchen waste and taking care to water them with the EMAS solution ( 2 ml EMAS/1 I water). The entire pile is covered with straw to retain moisture and protect microorganisms from solar radiation. This process also makes it possible to limit losses by evaporation.

The different bokashis were prepared on the NGO-IAPEDEL production site according to the recommendations of the Songhaï center over a period of 30 days. The compost used was produced and marketed by the Songhaï center. Table 1 shows the chemical characteristics of the different fertilizers used.

\section{Biopesticide}

The solution of EM5 biopesticide obtained after fermentation, in the presence of EM, plant extracts of neem leaves (Azadirachta indica) and tobacco (Nicotiana tabacum), dried chilli fruits (Capsicum spp) and pods of garlic (Allium sativum) was purchased at the Songhai Regional Center in Porto-Novo and used at the rate of 11 in 100 l of water.

\section{Experimental design}

The experiment design was a split plot with a two factor. The main factor was the type of organic fertilizer (amendment), and the couple (fertilizer application and frequency of application of EM5) as a sub plot factor the main factor (type of amendment) has three (3) levels: Co, Bs and Bf.

The secondary factor had four (4) levels:

- (0 t/ha, 0): No application of fertilizer and no application of biopesticide (TO);

- $\quad(20 \mathrm{t} / \mathrm{ha}, 0)$ : Application of fertilizer and no application of biopesticide (T1);

- $\quad(20 \mathrm{t} / \mathrm{ha}, 1)$ : Application of fertilizer and application of biopesticide once a week (T2);

- $\quad$ (20 t/ha, 2): Application of fertilizer and application of biopesticide twice a week (T3).

The $20 \mathrm{t} / \mathrm{h}$ a dose as used due to the pratice at the Songhai center and also the recommendation made by Assogba-Komlan, et al. 2012 [25] in market garden production in South-Benin.

Twelve (12) randomized treatments were therefore constituted and repeated 3 times. A total of 36 experimental units were set up for the cultivation of amaranth. The dimensions of the experimental units (boards) were $1 \mathrm{~m} \times 1 \mathrm{~m}$. Aisles of $0.5 \mathrm{~m}$ were maintained between the experimental units. The density of the plants per bed was 25 , a spacing of $20 \mathrm{~cm} \times 20$ $\mathrm{cm}$. A spacing of $10 \mathrm{~cm}$ on each side was observed to limit the border effects.

\section{Plant material and cultural operations}

The local variety of Amaranthus hybridus was used in our experiment. The seeds were purchased from an approved structure in the place called "Affaire Paysan", located in Cotonou. The nursery lasts 18 days. The planting was carried out one week after the basic manuring to stabilize the $\mathrm{pH}$ and the biological activity of the microorganisms at the level of the different bokashis.

\section{Data Collected}

\section{Growth data}

Number of leaves, leaf length, height of plants and diameter at the crown were collected on each elementary plot from 10 plants chosen at random every five days. The incidence and severity of the beet moth (Spoladea recurvalis) and stinking locust (Zonocerus variegatus) were assessed by weekly observations on the entire plot. The yield (R) based on fresh matter was evaluated by weighing the foliar biomass harvested on each elementary plot.

Profitability was assessed by calculating gross value added (GVA). It takes into account the values of gross product (GP) and intermediate consumption (IC).

GVA $=$ GP-IC

The gross product was calculated from references obtained on the market. Thus the price of a $300 \mathrm{~g}$ bunch of amaranth is sold at 50 FCFA, covering the period from May to June. The calculation of intermediate consumption for vegetable production takes into account the cost of raw materials and services purchased by producers for vegetable production. The raw materials take into account the cost of the formulation of bokashis, seeds and biopesticide. Daily plank confession, maintenance, watering and soil amendment and phytosanitary treatment activities were assessed based on the number of hours they were performed. As a result, it was a question of summing up the hours for the different activities, in order to obtain a number of days devoted by considering an eight (8) hour work day. This made it possible to evaluate the profitability of the different treatments in man/day.

\section{Data analysis}

Linear mixed-effects models with amendment, application and period were considered fixed factors, and block as 
Citation: HOUENOU ACE, KOURA TW, Dieudonné G, et al. (2021) Evaluation of the Effectiveness of Bokashis, Compost and Biopesticide Solution on the Productivity of Amaranth (Amaranthus hybridus) in Southern Benin. J Hortic Sci Res 4(1):161-170
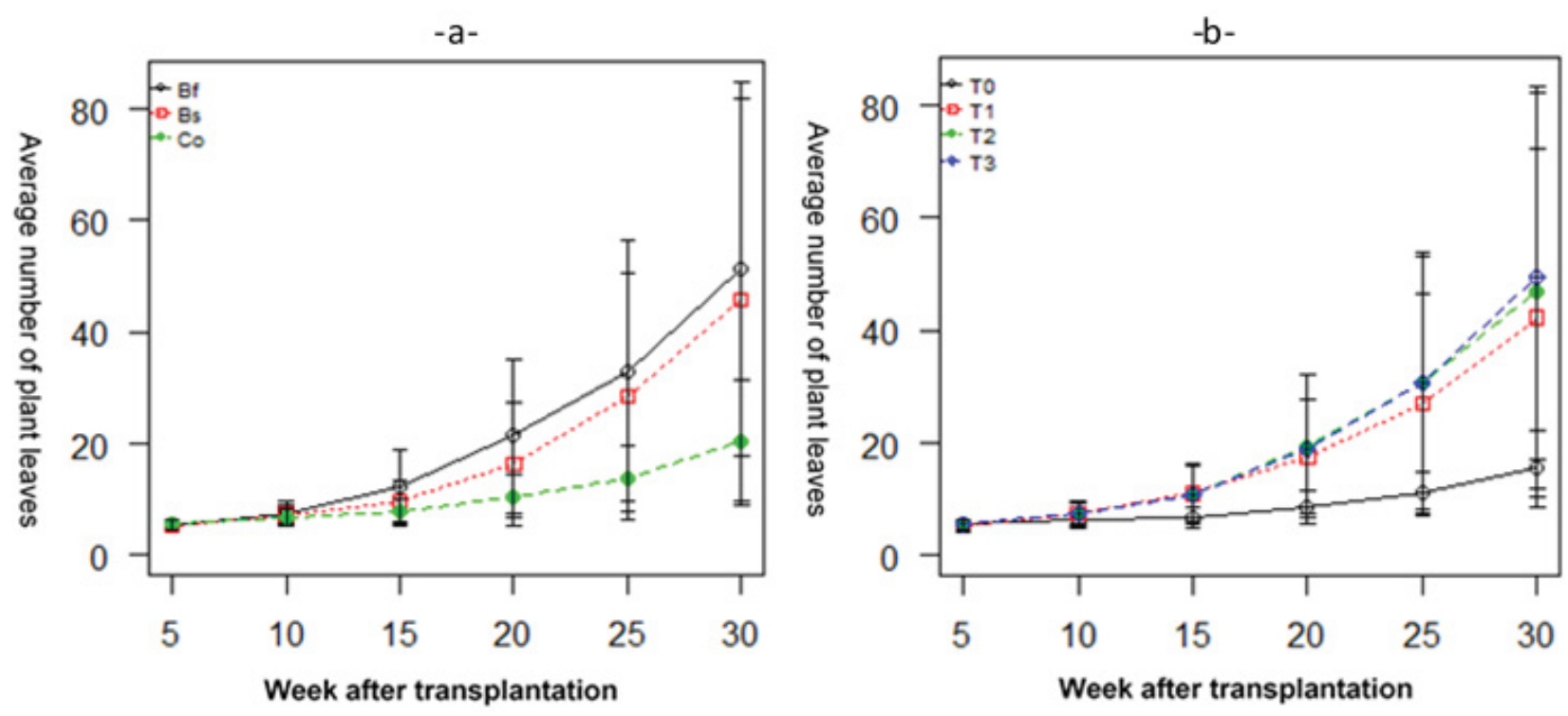

Figure 1: Evolution of the number of leaves of amaranth plants according to the different fertilizers (a) and treatments (b).

Co: Compost based on decomposable residues from the Songhaï center; Bs: Bokashi made from bran and rice husk with Moringa leaves as a ferment; Bf: Bokashi made from bran and rice husk with poultry litter as a starter; T0: No amendment-no biopesticide; T1: Amendment only; T2: Amendment + one biopesticide treatment/week and T3: Amendment + two biopesticide treatments/week).

random factor were performed to assess the effect of different fertilizers on the growth, incidence and severity of pests present using the Imer function [26] of the ImerTest packages and Ime4. For the performance parameters, the normality and homogeneity of the data were verified by Shapiro-Wilk and Leven tests, respectively. Failure to comply the yield parameter with these conditions led to the performance of the Kruskal-Wallis test and made it possible to highlight the differences in the median between the treatments (amendment and application). The posthoc.kruskal.dunn.test function of the PMCMR and multcompView packages [27] was used to perform the median structuring test of Tukey and boxplots. All the statistical analyzes were carried out in the R software version 3.5.1 [28].

\section{Results}

\section{Effect of different treatments on growth param- eters}

Number of leaves of amaranth plants: Leaf growth evolved slowly for the first 10 days after recovery. The leaf emission rate accelerates over the following days regardless of the type of amendment and the frequency of biopesticide application (Figure 1a and Figure 1b). The bokashis Bf and Bs had the highest numbers of leaves with significant differences compared to that of the compost from the $20^{\text {th }}$ day (Figure 1a). On average, 51,45 and 20 leaves were obtained respectively with the addition of $\mathrm{Bf}, \mathrm{Bs}$ and $\mathrm{Co}$ on the $30^{\text {th }}$ day.

Although, the application of the biopesticide twice and once per week seems to increase the number of leaves of amaranth plants, no significant difference was observed compared to the absence of biopesticide treatment $(P>0$, 05). Compared to the control treatment (TO), the addition of amendments at a dose of $20 \mathrm{t} / \mathrm{ha}$, with/without the applica- tion of biopesticide ( $T 1, T 2$ and $T 3$ ), significantly improves the speed of leaf growth from the $20^{\text {th }}$ day $(P<0.001)$ Maximum values on the 30th day at the rate of $49,47,43$ and 15 sheets respectively for the $\mathrm{T} 3, \mathrm{~T} 2, \mathrm{~T} 1$ and $\mathrm{T} 0$ treatments.

Height of amaranth plants: Regardless of the type of amendment and the frequency of application of the biopesticide, amaranth plants grew slowly for the first 10 days after recovery. Although the trend of the height was the same, the effects varied from one treatment to another (Figure 2a and Figure $2 b$ ). As noted at the level of leaf growth, the contribution of bokashis $\mathrm{Bf}$ and Bs induce a better significant growth, compared to the application of the compost from the $25^{\text {th }}$ day to reach respective maximum average values of $20.08 \mathrm{~cm}$, $18.55 \mathrm{~cm}$ and $11.93 \mathrm{~cm}$ on the $30^{\text {th }}$ day (Figure 2a). No significant difference was noted between the bokashis compared to each other. The amendment contribution at a dose of 20 $\mathrm{t} / \mathrm{ha}$, with/without the application of biopesticide (T1, T2 and T3) significantly increased plant height compared to the control treatment (TO) at $30^{\text {th }}$ day. On the other hand, the highest heights were obtained with the application of $\mathrm{T} 2$ biopesticide $(20.5 \mathrm{~cm})$.

Neck diameter: The diameter at the neck changes slowly the first 5 days after recovery then accelerates on the following days until the $30^{\text {th }}$ day regardless of the type of treatment and fertilizers (Figure 3 ).

Fifteen (15) to $30^{\text {th }}$ days after the amaranth plants were transplanted, the maximum neck diameter were obtained with bokashi Bf $(6.02 \mathrm{mn})$ and $\mathrm{Bs}(5.9 \mathrm{mn})$. The application of the compost $(3.21 \mathrm{mn})$ induced a low significant diameter compared to the application of bokashis (Figure 3a).

Although very highly significant differences were obtained with the amendment contribution with/without biopesticide 

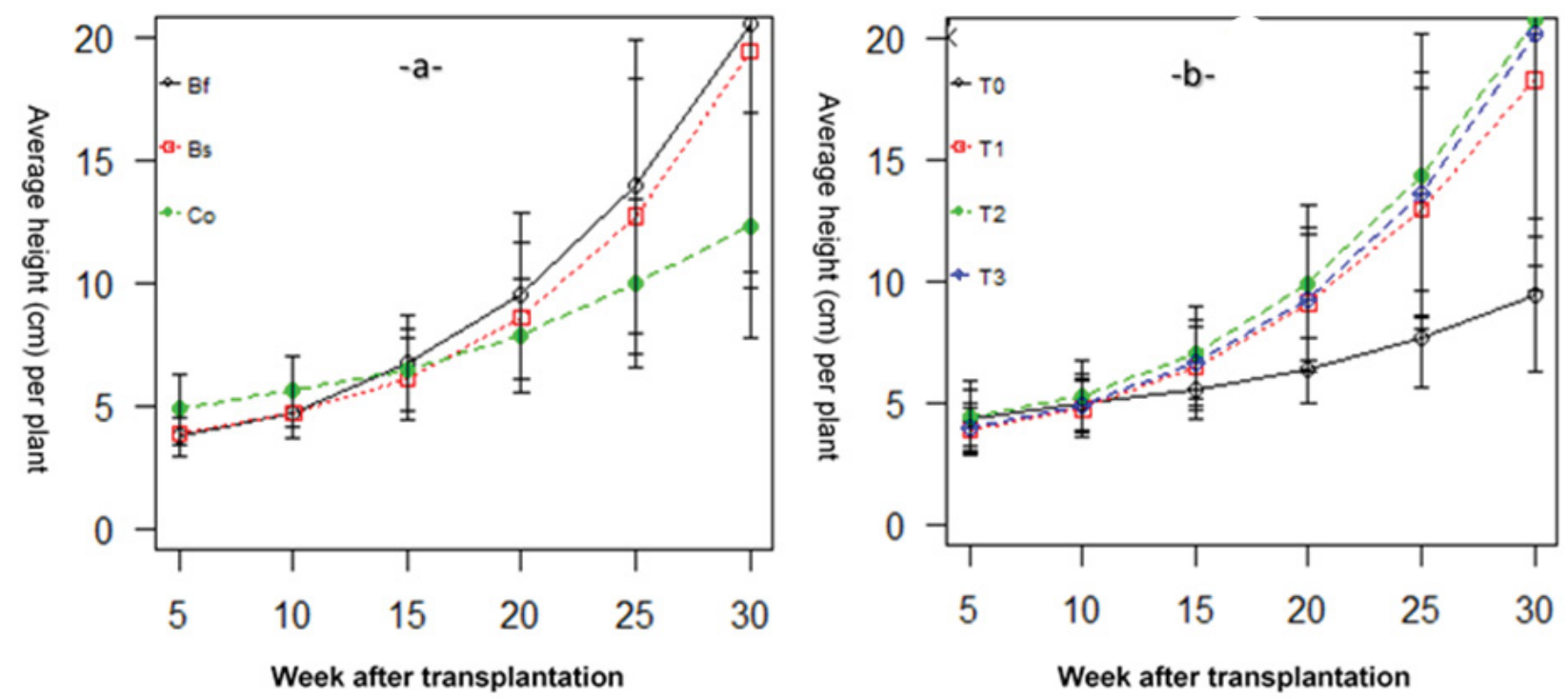

Figure 2: Evolution of the average height $(\mathrm{cm})$ per plant according to the different fertilizers (a) and treatments $(\mathrm{b})$.

Co: Compost based on decomposable residues from the Songhaï center; Bs: Bokashi made from bran and rice husk with Moringa leaves as a ferment; Bf: Bokashi made from bran and rice husk with poultry litter as a starter; T0: No amendment-no biopesticide; T1: Amendment only; T2: Amendment + one biopesticide treatment/week and T3: Amendment + two biopesticide treatments/week).
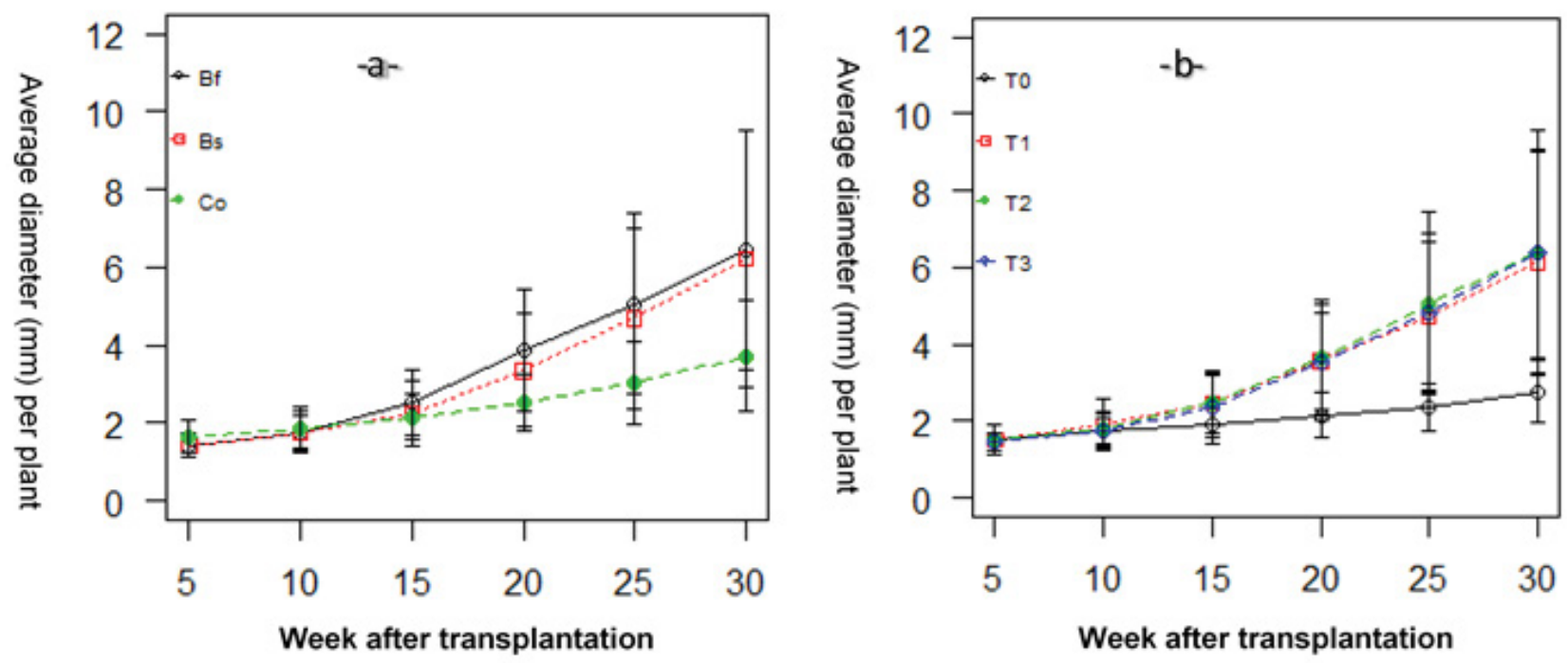

Figure 3: Evolution of the average neck diameter $(\mathrm{mn})$ per plant according to the different fertilizers (a) and treatments (b).

Co: Compost based on decomposable residues from the Songhaï center; Bs: Bokashi made from bran and rice husk with Moringa leaves as a ferment; Bf: Bokashi made from bran and rice husk with poultry litter as a starter; T0: No amendment-no biopesticide; T1: Amendment only; T2: Amendment + one biopesticide treatment/week and T3: Amendment + two biopesticide treatments/week).

(T1, T2, T3) compared to the control (T0) in the diameter at the neck (Figure 3b); no difference was observed between the T1, T2 and T3 applications. On the other hand, the highest diameter are obtained due to the application of fertilizer and biopesticide twice and once a week $(T 3, T 2)$ with respective mean values of 6.04 and $6.03 \mathrm{mn}$ (Figure $3 \mathrm{~b}$ ).

\section{Effect of bokashis, compost and biopesticide on amaranth yield}

Effect of amendment and application on first cut yield:
Bokashis applied at a rate of $20 \mathrm{t} /$ ha produced the highest fresh yields during the first cut, with a significant difference compared to the compost applied at a same rate. Bokashi made from Moringa leaves as a ferment produced the higher yield $(6.16 \mathrm{t} / \mathrm{ha}$ ) compared to bokashi made from Bf poultry manure (5.49 t/ha) and the compost (1.52 t/ha) (Figure 4a). Regarding the using of the biopesticide in combination with the amendment contribution, significant differences were obtained after application of the biopesticide once a week (6.1 t/ha) compared to the control T0 (1.49 t/ha). The combina- 
Citation: HOUENOU ACE, KOURA TW, Dieudonné G, et al. (2021) Evaluation of the Effectiveness of Bokashis, Compost and Biopesticide Solution on the Productivity of Amaranth (Amaranthus hybridus) in Southern Benin. J Hortic Sci Res 4(1):161-170

tion of the amendment effect and the application of biopesticide, according to the compost, were not allowed to obtain significant differences between all treatments applications (T0, T1, T2 and T3).

On the other hand, the BsT2 (6.87 t/ha) and BfT2 (5.93 $\mathrm{t} / \mathrm{ha}$ ) treatments induce significant differences compared to their control BsT0 (1.02 t/ha) and BfT0 (1.39 t/ha) (Figure 4a).

Effect of amendments on total yield: According to the first yield cut, the total fresh yield was depended of the types of fertilizers and treatments. The different bokashis applied at the $20 \mathrm{t} / \mathrm{ha}$ rate allowed to obtain significant difference compared to compost application. The highest yields were obtained using bokashis Bs and Bf followed by the compost with/without biopesticide. With the average yields respectively who was a 7,98 t/ha to bokashi (Bs); 7,392 t/ha to bokashi (Bf) and $2 \mathrm{t} /$ ha for the compost (Co).

In addition, the highest amaranth yield were achieved using two (2) or one (1) application of biopesticide with the amendment of bokashis at $20 \mathrm{t} /$ ha rate. In short, the maximum yields were obtained with the treatments BsT2, BsT1 and BfT2 (8.43 and 8.25 t/ha and 8.06 t/ha, respectively) (Figure $4 b)$.

Also you noticed that no significant difference was ob- tained between the application of compos and the biopesticide application. The Songhaï compost was not able to improve the yield of the amaranth in this study (Figure 4b).

Effect of amendments on the incidence and severity of pigweed pests: The pests retained in the amaranth crop were defoliating insects, including the stinking locust and the beet moth caterpillars. The symptom retained was linked to the destruction of the leaves (eaten and perforated on at least half of the leaf surface). According to the results of linear mixed-effects models, differences are noted with the application made $(p=0.05)$ on the incidence of attacks (Table 2 ).

The presence of symptoms was more noted in the Bs amendments, with the T1 treatment (addition of amendment without biopesticide). More than $20 \%$ of plants under BsT1 show leaves that are punctured and/or eaten (Figure 5a).

In terms of severity, although no significant difference was observed, the T3 treatment (supplementation and application of biopesticide twice a week) reduced the severity of pest attacks (Figure $5 b$ ).

The length of the error bars at the (Figure 5b) level helps to explain on the one hand that the concentration of the values on which the average was calculated is low, i.e. that the value of the average is on the one hand uncertain due to the
Yield of $1^{\text {st }}$ cut $(t / h a)$

-a-
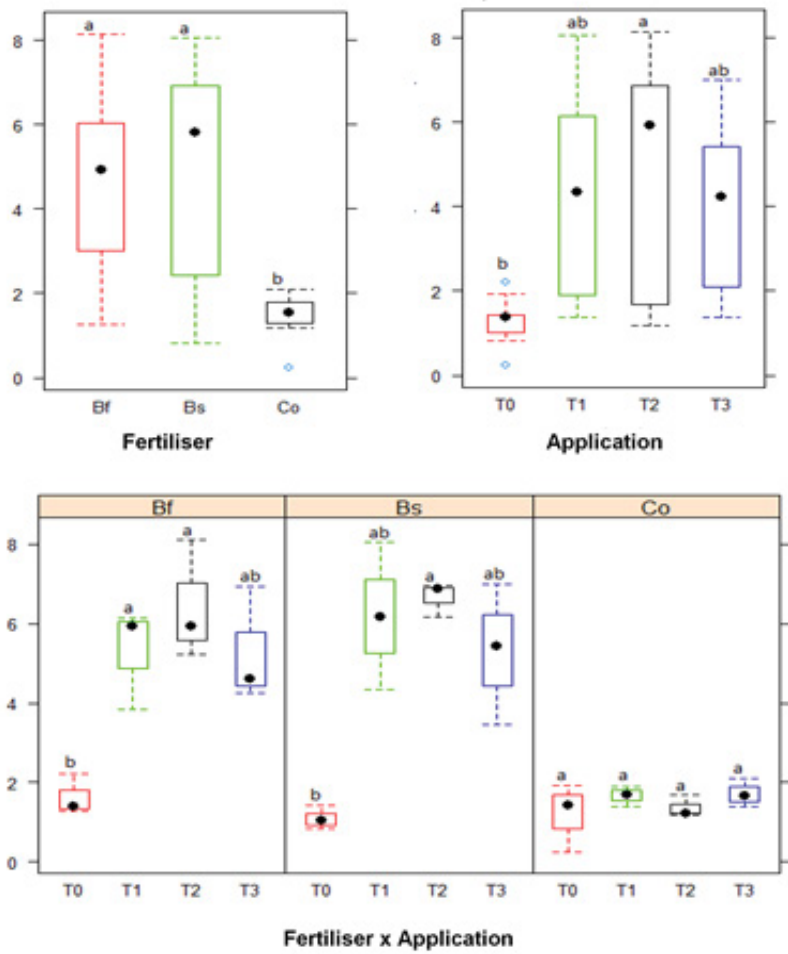

Total yield ( $1^{\text {st }} \& 2^{\text {sd }}$ cut) (t/ha)

-b-
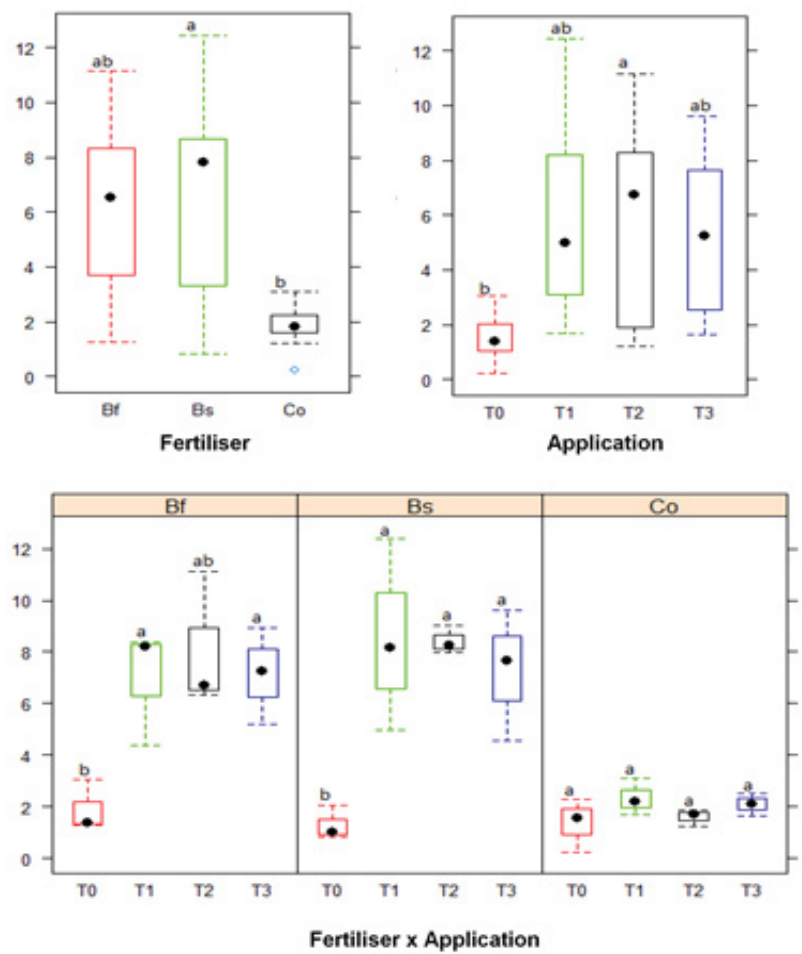

Figure 4: Effect of treatments on amaranth yield (a: Yield of $1^{\text {st }}$ cut; $b$ : Total yield).

Co: Compost based on decomposable residues from the Songhaï center; Bs: Bokashi made from bran and rice husk with Moringa leaves as a ferment; Bf: Bokashi made from bran and rice husk with poultry litter as a starter; TO: No amendment-no biopesticide; T1: Amendment only; T2: Amendment + one biopesticide treatment/week and T3: Amendment + two biopesticide treatments/ week). 
Citation: HOUENOU ACE, KOURA TW, Dieudonné G, et al. (2021) Evaluation of the Effectiveness of Bokashis, Compost and Biopesticide Solution on the Productivity of Amaranth (Amaranthus hybridus) in Southern Benin. J Hortic Sci Res 4(1):161-170

Table 2: Effect of amendments and their application on the incidence and severity of pests in amaranth plants.

\begin{tabular}{|l|l|l|l|l|}
\hline Paramter & Statistic & Amendement (AM) & Application (A) & AM x A \\
\hline Pest incidence & Value of F & 0.07 & 2.68 & 0.80 \\
\cline { 2 - 5 } & $\operatorname{Pr}(>$ F) & 0.931 & 0.050 & 0.573 \\
\hline Pest severity & Value of F & 0.70 & 0.94 & 0.65 \\
\hline & $\operatorname{Pr}(>$ F) & 0.497 & 0.423 & 0.693 \\
\hline
\end{tabular}

Table 3: Gross value added (GVA) and minimum wage (GVA/m.d) man per day for the cultivation of amaranth.

\begin{tabular}{|l|l|l|l|l|l|l|l|l|l|l|l|l|}
\hline Treatments & CoT0 & CoT1 & CoT2 & CoT3 & BsT0 & BsT1 & BsT2 & BsT3 & BfT0 & BfT1 & BfT2 & BfT3 \\
\hline GVA for $400 m^{2}$ & 2932 & -2257 & -12364 & -18110 & 2678 & 2691 & -4169 & -15816 & 4873 & 11352 & 7705 & -16348 \\
\hline Number m.d & 23 & 25,75 & 26,875 & 28 & 23 & 25,75 & 26,875 & 28 & 23 & 25,75 & 26,875 & 28 \\
\hline GVA m.d & 127 & -88 & -460 & -647 & 116 & 104 & -155 & -565 & 212 & 441 & 287 & -584 \\
\hline
\end{tabular}
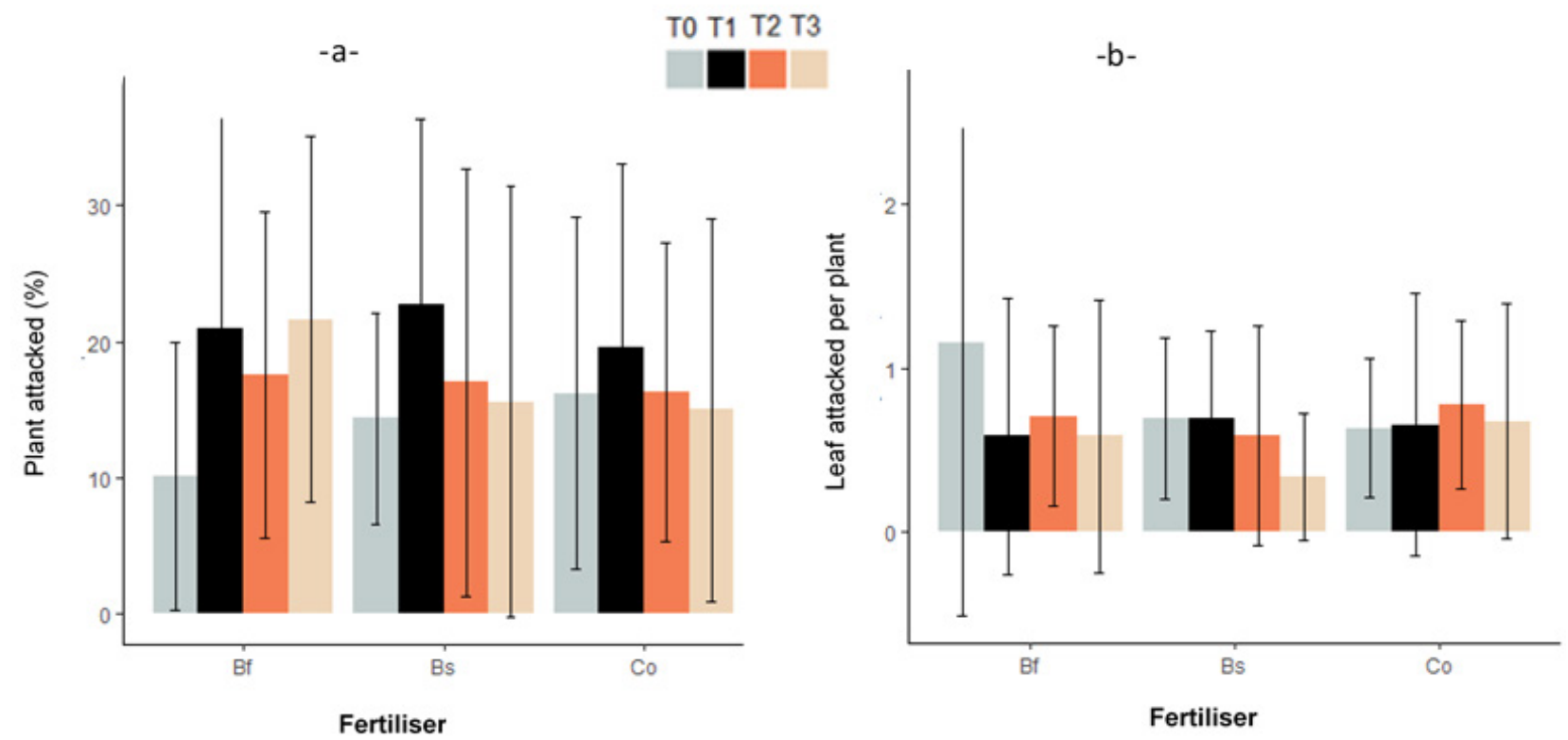

Figure 5: Incidence and severity of amaranth pest (-a- : Incidence of amaranth pest; -b- : Severity of amaranth pest).

Co: Compost based on decomposable residues from the Songhaï center; Bs: Bokashi made from bran and rice husk with Moringa leaves as a ferment; Bf: Bokashi made from bran and rice husk with poultry litter as a starter; T0: No amendment-no biopesticide; T1: Amendment only; T2: Amendment + one biopesticide treatment/week and T3: Amendment + two biopesticide treatments/ week).

character of the study and the different pests considered. On the average 1 to 2 leaves per plant are perforated and/or eaten at more than $1 / 2$.

\section{Economic analysis of amaranth production}

The controls without input (COTO, BsT0 and BfTO), bokashi $B f$ alone (BfT1) and with one biopesticide treatment per week (BfT2), and bokashi Bs only (BfT1) generated a positive GVA while the other treatments resulted in losses. Spraying the EM5 biopesticide systematically decreased the GVA generated by the application of a given amendment (Table 3 ).

The highest labor remuneration was obtained for the application of Bokashi Bf alone which generates GVA/ m.d of 441 FCFA for the production of amaranth.

\section{Discussion}

Whatever the parameter considered, the behavior of the plants depended on the type of amendment, but also on the applications made. In general, the addition of bokashi (Bs or Bf) significantly improved the growth and yield of amaranth plants compared to the compost. The application of the biopesticide solution (T2 and T3) improved height (Figure 2), number of leaves (Figure 1), the neck diameter (Figure 3) compared to treatment without the biopesticide (T1).

The differences observed between bokashis and the compost on growth parameter depends on the properties of the fertilizers. From a chemical point of view, bokashis have contented higher nutrient ( $\mathrm{N}, \mathrm{P}$ and $\mathrm{K}$ ) than the compost.

The use of organic matter improves soil properties by im- 
Citation: HOUENOU ACE, KOURA TW, Dieudonné G, et al. (2021) Evaluation of the Effectiveness of Bokashis, Compost and Biopesticide Solution on the Productivity of Amaranth (Amaranthus hybridus) in Southern Benin. J Hortic Sci Res 4(1):161-170

proving the availability and aeration of nutrients and water through improved structure [29-34]. The different nutrients higher at the levels of bokashis compared to the compost are made available to amaranth plants for the improvement of growth. Similar results were obtained in Nigeria where amendments based on cassava peels and poultry manure applied at $20 \mathrm{t} /$ ha produced the highest values for leaf count, plant height and growth parameter to Celosia argentea [35]. Likewise in Benin, the application of amendment based on palm nut residues and animal droppings improved the growth of amaranth and African nightshade plants and horsehair [34,36-38]. These results are in line with the recommendations of Assogba, et al. [15] according to which a dose of 20 $\mathrm{t} / \mathrm{ha}$ is sufficient to increase plant growth of Solanum macrocarpon.

Bokashis applied at a rate of $20 \mathrm{t} /$ ha with/without biopesticide produced fresh significantly higher total biomass than the compost applied with or without biopesticide for Amaranthus crops (Figure 4). These results are similar to those obtained by Polmans [39], on lettuce with the addition of bokashi. Plants take advantage of the mineral elements provided by amendments to develop $[40,41]$. The highest yield obtained using bokashi Bs with biopesticide at the rate of one treatment per week ( $8.43 \mathrm{t} / \mathrm{ha}$ ) was situated between the yields obtained by Koussihouèdé, et al. 2016 [42], on the culture of amaranth in southern Benin with composted excrements from small ruminants ( $4.8 \mathrm{t} / \mathrm{ha})$ and poultry litter (12.9 $\mathrm{t} / \mathrm{ha}$ ) at a rate of $20 \mathrm{t} / \mathrm{ha}$. In Benin, the expected yields, with a soil +/- rich in organic matter and a supply of urea at a rate of $75 \mathrm{t} /$ ha are between 7 and $10 \mathrm{t} /$ ha of fresh matter [43]. It is therefore confirmed that bokashi can be used as anorganic fertilizer for improving the yield in vegetable production in Benin.

According to pests of Amaranthus in this study (Figure 5), the treatment with the biopesticide twice a week reduced the incidence of amaranth defoliating pests. Water extracts made from plants and plant parts are able to control the population of bioagressors such as those noted by Houadakpode 2018 [44], where botanical extracts based on water extracts of Ocimum significantly reduced populations of Lipaphis erysimi, Bemisia tabaci and Selepa docilis compared to the control. These observations are in the same direction as those of Deleixhe [45], who noted a reduction in attacks by defoliating insects with the application of a solution of biopesticide M5 (based on ME, garlic, onion, etc.) on radish plants. This result may be possible by the composant of this preparation such as the presence of EM, plant extracts of neem leaves (Azadirachta indica) and tobacco (Nicotiana tabacum), dried chilli fruits (Capsicum spp) and pods of garlic (Allium sativum). The some indegrients without EM, was been noticed by several authors as repulsive pest plant control [46]. The role of EM, according to Higa [47] is to facilitate the anaerobic fermentation and to strengthen the plant system defense.

We notice that, none of the salaries compared allows a remuneration for the work necessary for their application equivalent to that of the minimum daily wage in the informal sector (965 FCA/working day, or 1.47 EUR/working day) Table 3. This is explained by the high cost of the ingredients neces- sary for the preparation of the other bokashi (Bs), especially rice bran and honey, and of the biopesticide EM5 (sold 2,500 FCFA/liter by the Songhaï center), and by the weak effects of the compost and the biopesticide EM5 on the yield of amaranth.

\section{Conclusion}

This study has a descriptive and analytical component to find alternatives for the production and improvement of organic matter by formulating Bokashi. Thus it over a short period of a month, by-products can be valued as an amendment and used for agricultural production, case of market gardening.

It emerges from this study that: The amaranth production it is possible with the bokashis using at the $20 \mathrm{t} / \mathrm{ha}$. The poor performance recorded for the supply of this compost using in this study (Songhaï compost) can no doubt be explained by its low content of organic matter ( $10 \%$ of the fresh matter) and therefore of nutrients also this not help us to generate the result about all composts.

It is be interested to combine the bokashis with/without one or two biopesticide sprays per week to obtain the high biomass and control pests incidence and severity.

Further studies should be done with other types of compost (preferably self-made) and different bokashis at different doses to assess the effect on amaranth and other vegetable crops and must include biopesticide application.

It would also be interesting to evaluate in other studies the environmental impacts of the application of bokashis (because of acid $\mathrm{pH}$ ) as an alternative to amendment in market gardening systems in southern Benin.

\section{References}

1. FAO et Commission de la CEDEAO (2018) Profil national genre des secteurs de l'agriculture et du développement rural- Bénin. Série des Évaluations Genre des Pays. Cotonou.

2. FAO (2015) Croissance Agricole en Afrique de l'Ouest: Facteurs déterminants de marché et de politique.

3. Singbo GA, Nouhoheflin T, Idrissou L (2004) Etude des perceptions sur les ravageurs des légumes dans les zones urbaines et périurbaines du sud Bénin. INRAB.

4. Yolou I, Yabi I, Kombieni F, et al. (2015) Maraîchage en milieu urbain à Parakou au Nord-Bénin et sa rentabilité économique. Int J Innov Sci Res 19: 290-302.

5. Hounkpodoté MR et Tossou CC (2001) Profil des interactions entre la problématique foncière et le développement de l'agriculture urbaine dans la ville de Cotonou et environs. Chambre d’Agriculture du Bénin.

6. Kakai HF, Kakai SG, Tohouegnon AG (2010) Agriculture urbaine et valorisation des déchets au Bénin: Une approche de développement durable. [VertigO] La revue électronique en sciences de l'environnement.

7. Singbo GA, Nouhoheflin T, Idrissou L, et al. (2008) Facteurs socio-économiques déterminant la lutte contre les ravageurs des légumes en zones urbaines au Sub Bénin. In: Agricultures et développement urbain en Afrique subsaharienne: Environnement et Enjeux Sanitaires. 19-29. 
Citation: HOUENOU ACE, KOURA TW, Dieudonné G, et al. (2021) Evaluation of the Effectiveness of Bokashis, Compost and Biopesticide Solution on the Productivity of Amaranth (Amaranthus hybridus) in Southern Benin. J Hortic Sci Res 4(1):161-170

8. Kanda M, Akpavi S, Wala K, et al. (2014) Diversité des espèces cultivées et contraintes à la production en agriculture maraichère au Togo. Int J Biol Chem Sci 8: 115-127.

9. Matthews CR (2008) Pesticide application methods, 3rd edition. Wiley-Blackwell.

10. Xiang H, Nuckols JR, Stallones LA (2000) Geographic information assessment of birth weight and crop production patterns around mother's residence. Environ Res 82: 160-167.

11. Levario-Carrillo M, Amato D, Ostrosky-Wegman P, et al. (2004) Relation between pesticide exposure and intrauterine growth retardation. Chemosphere 55: 1421-1427.

12. Ninsin KD (2015) Cross-resistance assessment cartap and esfenvalerate selected strains of the diamondback moth, Plutella $x y-$ lostella (L.) (Lepidoptera: Plutellidae). WAJAE 23: 1-6.

13. Agboyi LK, Ketoh GK, Martin T, et al. (2016) Pesticide resistance in Plutella xylostella (Lepidoptera; Plutellidae) populations from Togo and Benin. International Journal of Tropical Insect Science 36: 204-210.

14. Ahmad M, Rafiq M, Arif MI, et al. (2011) Toxicity of some commonly used insecticides against coccinella undecimpunctata ( $\mathrm{Co}$ leoptera: Coccinellidae). Pakistan J Zool 43: 1161-1165.

15. Assogba-komlan F, Anihou P, Achigan E, et al. (2007) Pratiques culturales et teneur en éléments anti nutritionnels (nitrates et pesticides) du Solanum macrocarpum au sud du Bénin. 7: 21.

16. Ahouangninou C CA (2013) Durabilite de la production maraichere au sud-benin : Un essai de l'approche ecosystemique. Environnement, santé et développement durable : Université d'Abomey-Calavi.

17. Agueh V, Degbey CC, Sossa-Jerome C, et al. (2015) Niveau de contamination des produits maraîchers par les substances toxiques sur le site de Houéyiho au Bénin. Int J Biol Chem Sci 9 542-551.

18. Trabelsi M (2018) Comment mesurer la performance agroécologique d'une exploitation agricole pour l'accompagner dans son processus de transition ? Géographie.

19. Altieri MA (1983) "The question of small farm development: Who teaches whom?" Agriculture, Ecosystems and Environment 9: 401-405.

20. Stassart PM, Baret Ph, Grégoire J-Cl, et al. (2012) 'L' agroécologie: Trajectoire et potentiel Pour une transition vers des systèmes alimentaires durables. 1: 1-21.

21. Altieri MA (1995) Agroecology: The science of sustainable agriculture. In : Boulder, Colorado, Westview Press.

22. Higa T (1986) Biological activities of marines organisms from Okinawa Ryukyu University, in japon-US. Seminar on Bio-Organic Marine Chemistry 4: 22.

23. Quemada M, Cabrera ML (1995) CERES-N model predictions of nitrogen mineralized from cover crop residues. Soil Science Society of American Journal 59: 1059-1065.

24. Igue AM, Saidou A, Adjanohoun A, et al. (2013) Evaluation de la fertilité des sols au sud et centre du Bénin. Bulletin de Recherches Agronomique du Bénin (BRAB).

25. Assogba-Komlan F, Yarou BB, Mensah A, et al. (2012) Les légumes traditionnels dans la lutte contre les bioagresseurs des cultures maraichères: Associations culturales avec le Tchayo (Ocimum gratissimum) et le yantoto (Launaea taraxacifolia). Fiche technique. Cotonou, Bénin : INRAB.
26. Kuznetsova A, Brockhoff PB, Christensen RHB (2017) "ImerTest Package: Tests in linear mixed effects models." Journal of Statistical Software $82: 1-26$.

27. Pohlert T (2014) The pairwise multiple comparison of mean ranks package (PMCMR). $R$ package.

28. R Core Team (2018) R: A language and environment for statistical computing. R Foundation for Statistical Computing, Vienna, Austria.

29. Crichton L, Ortega LB (2000) Report of resource recovery forum recycling achievements in Europe press. skipon north, York shine.

30. Laos F, Mazzarino MJ, Walter I, et al. (2002) Composting of fish offal and biosolids, in northwestern Patagonia. Bioresour Technol 81: 179-186.

31. Douglas JT, Aitken MN, Smith CA (2003) Effects of five non-agricultural organic wastes on soil composition and on the yield and nitrogen recovery on Italian ryegrass. Soil Use and Management 19: $135-138$.

32. Kowaljow E, Mazzarino MJ (2007) Soil restauration in semarid Patagonia: Chemical and biological response to different compost quality. Soil Biology \& Biochemistry 39: 1580-1588.

33. Weber J, Karczewska A, Drozd J, et al. (2007) Agricultural and ecological aspects of sandy soil as affected by the application of municipal solid waste composts. Soil Biology and Biochemistry 39: 1294-1302.

34. Houenou A C E (2013) Effect de trois composts et de leurs thés sur la croissance, le rendement et les nuisibles du Solanum macrocarpon. Mémoire de Licence en Agronomie.

35. Shokalu AO, Ojo AO, Adewoyin E, et al. (2011) Use of tithonia diversifolia and compost as soil amendements for growth and yield of celosia argentea. All African Horticultural Congress 149152.

36. Assea ED (2013) Effets de différents composts à base de résidus de noix de palme sur la production de l'Amarante (Amaranthus hybridus) sur sol ferrallitique au Sud du Bénin. Mémoire de licence en Agronomie.

37. Ruth M (2013) Effects de trois types de composts sur la croissance et le rendement de la grande morelle (Solanum macrocarpon) sur sol ferralitique au Sud du Bénin. Unité Universitaire de Cotonou/ Bénin (UUC).

38. Koura TW, Dagbenonbakin GD, Kindomihou VM, et al. (2015) Effect of composting of palm oil mill wastes and cow dung or poultry manure on Amaranthus hybridus growth and yield. Journal of Applied Biosciences. 86: 7918-7927.

39. Polmans A (2018) Étude comparative en vue de l'optimisation des propriétés physico-chimiques du bokashi produit par la coopérative "Udom Sorya " à Takéo. Haute école de CHARLEMAGNE.

40. Saidou A, Bachabi S FX, Padonou GE, et al. (2012) Effet de l'apport d'engrais organiques sur les propriétés chimiques d'un sol ferrallitique et la production de laitue au Sud Bénin. Rev.CAMESSérie A 13: 281-285.

41. Tognetti C, Mazzarino MJ, Laos F (2008) Compost of municipal organic waste: Effects of different management practices on degrability and nutrient release capacity. Soil Biology and Biochemistry 40: 2290-2296.

42. Koussihouèdé HK, Assogba-komlan F, Aholoukpè NSH, et al. 
Citation: HOUENOU ACE, KOURA TW, Dieudonné G, et al. (2021) Evaluation of the Effectiveness of Bokashis, Compost and Biopesticide Solution on the Productivity of Amaranth (Amaranthus hybridus) in Southern Benin. J Hortic Sci Res 4(1):161-170

(2016) Influence comparée de la litière de volaille et des déjections compostées de petits ruminants sur la productivité de l'amarante (Amaranthus cruentus L.) sur terre de barre au SudBénin. (Bulletin des Recherches Agronomiques du Bénin) BRAB Numéro 80: 14-23.

43. Adegbola PY, Adjovi Ahoyo N, Mensah PSE, et al. (2017) Recueil des technologies agricoles prometteuses développées par le système national de recherche agricole (SNRA) de 1996 à 2015. Bibliothèque Nationale du Bénin.

44. Houadakpode DS (2018) Valorisation des plantes aromatiques dans la gestion intégrée des principaux insectes ravageurs de la grande morelle au sud-bénin: Cas de Ocimum gratissimum et O. basilicum. Université de Liège, Faculté Agro-Bio Tech (Gembloux).
45. Deleixhe G (2012) 'Etude participative de l'impact agronomique et de la durabilite de plusieurs traitements de production agroecologique utilises par la petite agriculture familiale de carhuaz. Bioingenieur.

46. Yarou BB, Pierre Silvie, Assogba-Komlan F, et al. (2017) Plantes pesticides et protection des cultures maraichères en Afrique de l'Ouest (synthèse bibliographique). Biotechnol Agron Soc Environ 21: 288-304.

47. Higa T (1991) Microorganisms for agriculture and environment preservation. 